\title{
New stereoisomeric derivatives of jasmonic acid generated by biotransformation with the fungus Gibberella fujikuroi affect the viability of human cancer cells
}

\author{
Marcela Carvajal $^{1} \triangle \cdot$ Luis Espinoza $^{1} \cdot$ Silvia Caggia $^{2} \cdot$ Venera Cardile $^{2} \cdot$ Juan A. Garbarino $^{1}$ \\ Hugo Peña-Cortés ${ }^{3} \cdot$ Alessandra Russo $^{4} \square$ \\ 1 Laboratorio de Química de Productos Naturales y Síntesis Orgánica, Departamento de Química, Universidad Técnica Federico \\ Santa María, Valparaíso, Chile \\ 2 Department of Physiological Sciences, University of Catania, Catania, Italy \\ 3 Centro de Biotecnología “D. Alkalay L.", Universidad Técnica Federico Santa María, Valparaíso, Chile \\ 4 Department of Biological Chemistry, Medical Chemistry and Molecular Biology, University of Catania, Catania, Italy
}

$\triangle$ Corresponding authors: marcela.carvajal@usm.cl; ales0303@libero.it

Received October 26, 2010 / Accepted January 28, 2011

Published online: March 15, 2011

(c) 2011 by Pontificia Universidad Católica de Valparaíso, Chile

\section{ABSTRACT}

Background: Several studies have shown that (-)-Jasmonic acid, (+)-7-iso-Jasmonic acid and its methyl ester, methyl jasmonate, have anti-cancer activity in vitro and in vivo, exhibiting selective cytotoxicity towards cancer cells. The degree of activity of these molecules is strongly related to their stereochemistry. The biotransformation of known compounds, natural or synthesized, related to interesting biological activities, generates new molecules displaying new improved properties compared with the original ones, increasing its value and providing new more effective products. Therefore, based on the above rationales and observations, in this work a biotransformation protocol to modify the chemical structure of the plant hormone jasmonic acid by using the fungus Gibberella fujikuroi was established.

Results: The three jasmonic acid derivatives obtained, 3(S)-Hydroxy-2(R)-(2Z-pentenyl)-cyclopentane1(R)-acetic acid (1), 3(R)-Hydroxy-2(R)-(2Z-pentenyl)-cyclopentane-1(R)-acetic acid (2), 3-Hydroxy2(S)-(2Z-pentenyl)-cyclopentane-1(S)-acetic acid (3), were tested for cell-growth inhibition activity towards the human cancer epithelial cell line, the oral squamous carcinoma cells (KB). The results obtained show that jasmonic acid derivatives (1-3) are active on human cancer cells examined in different concentration ranges, with $\mathrm{IC}_{50}$ value less than of $25 \mu \mathrm{M}$. The compound 3 , with the same molecular structure of compounds 1 and 2, but with different stereochemistry, was more active confirming that the activity of jasmonate compounds is related to their stereochemistry and to substituents in the cyclopentane ring. In this study, we also tested the potential proapoptotic activity of compound 3, and our data suggest that it, as other jasmonate compounds, is able to trigger apoptotic death in cancer cells. This event may be correlated at an elevation of reactive oxygen species (ROS). Administration of $\mathrm{N}$-acetylcysteine (NAC) prevented compound 3 cytotoxicity.

Conclusions: This work shows for the by first time the production of hydroxylated derivatives of JA by biotransformation. The activity observed of these compounds in cancer cells is higher than the observed with JA and is strongly related to its stereochemistry.

Keywords: apoptosis, biotransformations, cancer cells, cell vitality, Gibberella fujikuroi, jasmonic acid

\section{INTRODUCTION}

The interest in medicinal plants and their biologically active derivatives has increased in recent years, in relation to the possible development of drugs for several pathologies of relevant social impact 
(Heinrich and Gibbons, 2001). In fact, it is well known that medicinal plants are described and used in respiratory disorders, in skin disorders, in cardiac diseases, in nervous and muscular disorders and in mental health (Heinrich and Gibbons, 2001; Ankli et al. 2002). With respect to potential antitumor activity, possible applications of natural compounds for cancer prevention and treatment have been extensively described. Currently, over $60 \%$ of the anti-cancer agents in use are derived from natural sources, i.e. plants, marine organisms and micro-organisms (Richardson, 2001; Wargovich et al. 2001; Chang et al. 2002; Tatman and Mo, 2002; Ravelo et al. 2004; Cardile et al. 2005; Cragg and Newman, 2005; Aggarwal and Shishodia, 2006). Several studies have evidenced in recent years that (-)Jasmonic acid (JA), (+)-7-iso-JA and its methyl ester, methyl jasmonate (MeJA), important members of the jasmonate family, have anti-cancer activity in vitro and in vivo, exhibiting selective cytotoxicity towards cancer cells while sparing normal blood lymphocytes, even when the latter were part of a mixed population of leukemic and normal cells drawn from the blood of chronic lymphocytic leukemia (CLL) patients (Flescher, 2007; Kniazhanski et al. 2008). Jasmonates, their precursors, or their metabolites, are known to accumulate in higher plants (Wasternack, 2007) and fungi (Miersch et al. 1999a). These molecules, ubiquitous in the plant kingdom, constitute a group of bioactive fatty acid derivatives that perform several important roles in growth, development, as well as biotic and abiotic stress (Rao et al. 2000; Dombrowski, 2003; Stratmann, 2003; Shan et al. 2007; Wasternack, 2007; Herman et al. 2008). Furthermore, their role in regulating defense responses against herbivore attack and infection by some pathogens has been extensively studied (Creelman and Mullet, 1997; Kessler and Baldwin, 2002; Li, et al. 2002; Wasternack and Hause, 2002; Rotem et al. 2003; Turner et al. 2004; Wasternack, 2007; Browse and Howe, 2008; Miersch et al. 2008; Browse, 2009). The degree of activity of molecules derived from jasmonates in plants is strongly related to their stereochemistry and type of substituent in the cyclopentane ring (Miersch et al. 1999b; Staswick, 2009). Structurally and biosynthetically, jasmonates belong to the family of oxygenated fatty acid derivatives, oxylipins, which are produced via the oxidative metabolism of polyunsaturated fatty acids. Jasmonate biosynthesis in plants is analogous to eicosanoid biosynthesis in animal cells. In animals, eicosanoids are synthesized from arachidonic acid (C20:4), while in plants linolenic acid (C18:3) is the major source of jasmonates. Upon its biosynthesis, jasmonic acid can be metabolized in a number of pathways including: methylation yielding $\mathrm{MJ}$, hydroxylation yielding tuberonic acid-related derivatives, conjugation of the carboxy terminus to amino acids or other adducts, reduction yielding cucurbic acid (CA) and its 6,7isomers containing a hydroxyl group instead of the keto function on the plane of the cyclopentane ring. They have also been detected as native compounds (Miersch et al. 1999a; Flescher, 2007).

The biotransformation of known compounds (natural or synthesized) related to interesting biological activities has been widely reported (Julsing et al. 2006; Leresche and Meyer, 2006). The new molecule generated by biotransformation displays new improved properties compared with the original molecule, increasing its value and providing new more effective products. Many of them are related to organoleptic properties and antibacterial, antiviral, and cytotoxic activities (Rao et al. 2002; Fraga et al. 2003). Taken for granted the existence of versatile enzymatic systems present in microorganisms like fungi, the chemical structure of specific plant molecules of interest can be modified to generate new compounds with improved properties. It is important to mention that the enzymatic activity of some microorganisms like fungi allows the incorporation of new chemical groups by reactions which are, generally, difficult to obtain by chemical synthesis (Azerad, 2000; Roberts, 2000). For instance, it has been reported that reductases and hydroxilases present in the enzymatic system of filamentous fungi, like Gibberella fujikuroi, are able to incorporate the new chemical groups in the molecule of interest with determined stereochemistry which normally cannot be achieved by the enzymatic machinery of the plant (Azerad, 2000; Lehman and Stewart, 2001; Boyd et al. 2002). The availability of a system to modify JA chemically and generate novel JA-derivatives with improved properties might provide new alternatives for the treatment of cancer. Therefore, based on the above rationales and observations, in this work a biotransformation protocol to modify the chemical structure of JA by using the fungus $G$. fujikuroi was established. The three JA derivatives obtained (1-3) (Figure 1) were tested for cell-growth inhibition activity towards the human cancer epithelial cell line, the oral squamous carcinoma cells (KB). Several biochemical parameters were tested, such as cell viability (MTT assay) and cell membrane integrity (lactate dehydrogenase release) (Russo et al. 2006). In addition, the fragmentation of genomic DNA determined by COMET assay and caspase-3 activity were examined (Russo et al. 2006). The possible induction of oxidative stress was evidenced by performing a fluorescent analysis of intracellular reactive oxygen species (ROS) production (Russo et al. 2006). 


\section{DERIVATES OF JA BY BIOTRANSFORMATION}

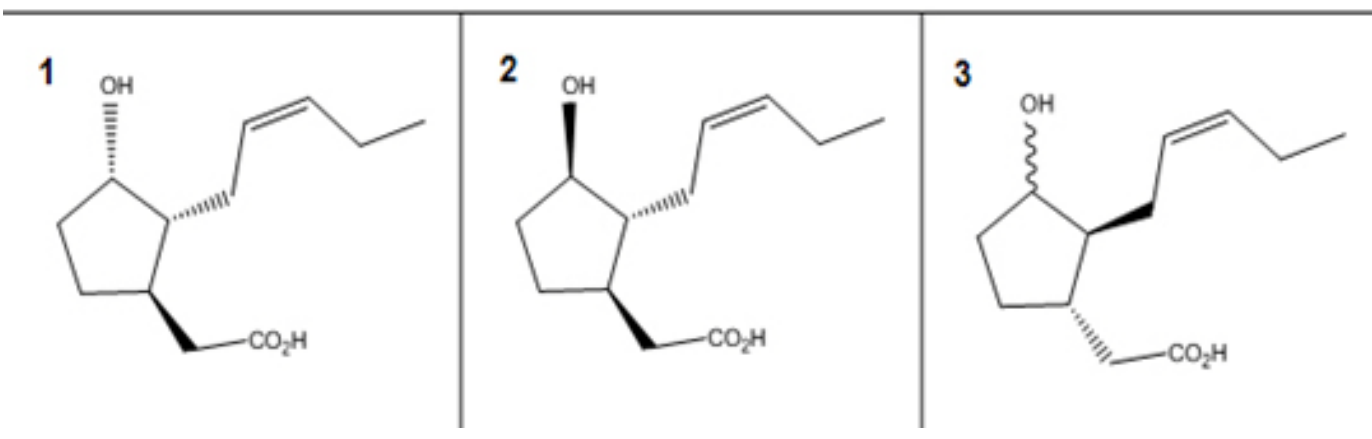

Fig. 1 Molecules obtained by biotransformation of JA. Molecules 1-3 derived from JA obtained by biotransformation using the G. fujikuroi fungus and characterized by NMR.

\section{MATERIALS AND METHODS}

\section{Chemicals}

All reagents were of commercial quality and were used as received. For biotransformation experiments ( \pm ) Jasmonic acid was obtained from Sigma-Aldrich (St. Louis, MO, USA). Deuterated solvents and general chemical reagents were obtained from Merck S.A. (Santiago, Chile). For cell culture studies 3(4,5-dimethylthiazol-2-yl)2,5-diphenyl-tetrazolium bromide (MTT), N-acetylcysteine (NAC) and $\beta$ nicotinamide-adenine dinucleotide (NADH) were obtained from Sigma Aldrich Co (St. Louis, USA). All other chemicals were purchased from Sigma Aldrich Co (St. Louis, USA) and GIBCO BRL Life Technologies (Grand Island, NY, USA).

\section{Biotransformation experiments and chemical analysis}

Microorganisms and culture conditions. The fungus G. fujikuroi was gracefully provided by Dr. B. Fraga, Natural Products and Agrobiology Institute, CSIC, Canary Islands, Spain. The strain of $G$. fujikuroi was grown either on solid PDA (potato dextrose agar) or in liquid medium according to Fraga et al. 2000. G. fujikuroi was grown on surface culture in petri plates at $26^{\circ} \mathrm{C}$ for 5 days on PDA medium (25 $\mathrm{ml}$ per flask) comprising potato extract $(4 \mathrm{~g} / \mathrm{L})$, glucose $(20 \mathrm{~g} / \mathrm{L})$, and agar $(15 \mathrm{~g} / \mathrm{L})$. The liquid medium used, according to the Fraga protocol modification, has the following composition: glucose (40 $\mathrm{g} / \mathrm{L}), \mathrm{NH}_{4} \mathrm{NO}_{3}(0.48 \mathrm{~g} / \mathrm{L}), \mathrm{KH}_{2} \mathrm{PO}_{4}(5 \mathrm{~g} / \mathrm{L}), \mathrm{MgSO}_{4} 7 \mathrm{H}_{2} \mathrm{O}(1 \mathrm{~g} / \mathrm{L}), \mathrm{pH} 5.0$ and $2 \mathrm{~mL}$ of trace elements such as $\mathrm{Co}\left(\mathrm{NO}_{3}\right)_{2}(0.1 \mathrm{mg} / \mathrm{L}),\left(\mathrm{NH}_{4}\right) \mathrm{Mo}_{7} \mathrm{O}_{24}(0.1 \mathrm{mg} / \mathrm{L}) \mathrm{FeSO}_{4} 7 \mathrm{H}_{2} \mathrm{O}(1 \mathrm{mg} / \mathrm{L}), \mathrm{CuSO}_{4} 5 \mathrm{H}_{2} \mathrm{O}(0.15$ $\mathrm{mg} / \mathrm{L}), \mathrm{ZnSO}_{4} 7 \mathrm{H}_{2} \mathrm{O}(1,61 \mathrm{mg} / \mathrm{L}), \mathrm{MnSO}_{4} 7 \mathrm{H}_{2} \mathrm{O}(0.1 \mathrm{mg} / \mathrm{L})$.

Biotransformation experiments. Figure 2 shows the protocol of the culture employed for the JA biotransformation by G. fujikuroi according to Fraga et al. (2000). In the macroculture, G. fujikuroi was grown in shake culture $(220 \mathrm{rpm})$ at $26^{\circ} \mathrm{C}$, light $(4000-4500 \mathrm{lux})$, in conical flasks $(250 \mathrm{~mL})$ each containing sterile medium $(50 \mathrm{~mL})$. JA (in $0.2 \%$ ethanol) was equally distributed into each bottle and the incubation allowed to continue for further 11 days. Two culture control conditions were employed: i) G. fujikuroi growing on media without JA; and ii) JA mixed with medium in absence of G. fujikuroi, to corroborate JA stability by the medium. In both biotransformation and control samples, the culture conditions and the extraction methods employed were exactly the same. To obtain the compounds, the supernatant was adjusted to $\mathrm{pH}$ with aqueous acid chloride or sodium hydroxide to enhance neutral, acidic and basic extraction with ethyl acetate. The extracts were dried over sodium sulphate, the solvent was evaporated and the residues were separated and purified by $\mathrm{CC}$ and then identified by Thin Layer Chromatography (TLC). 
Table 1. Cell growth inhibition, assayed using MTT test, of KB cells untreated and treated with jasmonic acid (JA) and compounds 1-3 at different concentrations for $\mathbf{7 2}$ hrs. Doxorubicin was used as a positive control. Stock solution of compounds was prepared in DMSO and the final concentration of this solvent was kept constant at $0.25 \%$. Control cultures received DMSO alone.

\begin{tabular}{|c|c|}
\hline Treatments & $\begin{array}{l}\text { KB cells } \\
I^{\prime} C_{50}{ }^{a}(\mu M)\end{array}$ \\
\hline Doxorubicin & $9.11 \pm 0.4$ \\
\hline Compound JA & $25.31 \pm 0.9$ \\
\hline Compound 1 & $17.07 \pm 0.4$ \\
\hline Compound 2 & $12.75 \pm 1.1$ \\
\hline Compound 3 & $9.27 \pm 0.8$ \\
\hline
\end{tabular}

${ }^{a}$ Results are expressed as $I C_{50}$ values $(\mu \mathrm{M}) \pm S D$. The $I C_{50}$ value, relative to untreated control, represents the concentration that inhibited cell vitality by $50 \%$. Each value represents the mean \pm SD of three experiments, performed in quadruplicate.

\section{Chemical analysis of extracts}

Silica gel (Merck 200-300 mesh) was used for column chromatography and silica gel plates HF-254 for TLC. TLC spots were detected by heating after spraying with $25 \% \mathrm{H}_{2} \mathrm{SO}_{4}$ in $\mathrm{H}_{2} \mathrm{O}$. The new identified spots were eluted from TLC by using petroleum ether/ ethyl acetate.

Low resolution mass spectra were recorded on a Shimadzu QP-2000 spectrometer at 70eV ionising voltage and are given as $\mathrm{m} / \mathrm{z}$ (\% rel. int.). NMR ${ }^{1} \mathrm{H}-,{ }^{13} \mathrm{C}$-(DEPT $135^{\circ}$ and DEPT $\left.90^{\circ}\right), 2 \mathrm{D}$ COSY, 2D $\mathrm{HSQC}$, and 2D HMBC spectra were recorded in $\mathrm{CDCl}_{3}$ solutions and are referenced to the residual peaks of $\mathrm{CHCl}_{3}$ at $\delta 7.26$ and $\delta 77.0$ ppm for ${ }^{1} \mathrm{H}$ and ${ }^{13} \mathrm{C}$, respectively, on a Bruker Avance 400 Digital NMR spectrometer, operating at $400.1 \mathrm{MHz}$ for ${ }^{1} \mathrm{H}$ and $100.6 \mathrm{MHz}$ for ${ }^{13} \mathrm{C}$. Chemical shifts are reported in $\delta$ ppm and coupling constants $(\mathrm{J})$ are given in $\mathrm{Hz}$.

\section{( \pm ) Jasmonic acid}

${ }^{1} \mathrm{H}$ NMR: $5.48-5.42(\mathrm{~m}, 1 \mathrm{H}, \mathrm{H}-10), 5.27-5.21(\mathrm{~m}, 1 \mathrm{H}, \mathrm{H}-9), 2.76(\mathrm{dd}, \mathrm{J}=8.1$ and $20.0 \mathrm{~Hz}, 1 \mathrm{H}, \mathrm{H}-4)$, 2.41-2.25 (m, 5H, H-8, H-6 and H-5a), $2.14(\mathrm{dd}, \mathrm{J}=8.0$ and $19.9 \mathrm{~Hz}, 1 \mathrm{H}, \mathrm{H}-1), 2.04(\mathrm{dd}, \mathrm{J}=7.4$ and $7.4 \mathrm{~Hz}, 2 \mathrm{H}, \mathrm{H}-11), 1.93-1.89(\mathrm{~m}, 1 \mathrm{H}, \mathrm{H}-2), 1.51$ (ddd, $\mathrm{J}=2.4 ; 8.7$ and $11.2 \mathrm{~Hz}, 1 \mathrm{H}, \mathrm{H}-5 \beta), 0.94(\mathrm{t}, \mathrm{J}=$ $7.4 \mathrm{~Hz}, 3 \mathrm{H}, \mathrm{H}-12) .{ }^{13} \mathrm{C}$ NMR: 37.7 (C-1), 53.8 (C-2), 218.9 (C-3), 38.7 (C-4), 27.1 (C-5), 37.7 (C-6), 178.1 (C-7), 25.4 (C-8), 124.8 (C-9), 134.2 (C-10), 20.5 (C-11), 14.1 (C-12); MS: 210 ([M] $\left.]^{+} 43 \%\right), 151$ (52\%), 142 (36\%), $83(100 \%), 79(25 \%)$.

\section{3(S)-Hydroxy-2(R)-(2Z-pentenyl)-cyclopentane-1(R)-acetic acid (1)}

${ }^{1} \mathrm{H}$ NMR: 5.53-5.38 (m, 2H, H-10 and $\left.\mathrm{H}-9\right), 3.90(\mathrm{dd}, \mathrm{J}=5.6$ and $11.2 \mathrm{~Hz}, 1 \mathrm{H}, \mathrm{H}-3), 2.55(\mathrm{dd}, \mathrm{J}=4.9$ and $15.2 \mathrm{~Hz}, 1 \mathrm{H}, \mathrm{H}-6 \mathrm{a}), 2.29(\mathrm{dd}, \mathrm{J}=8.8$ and $15.2 \mathrm{~Hz}, 1 \mathrm{H}, \mathrm{H}-6 \mathrm{~b}), 2.16-2.07(\mathrm{~m}, 4 \mathrm{H}, \mathrm{H}-11$ and $\mathrm{H}-8)$, 1.94-1.84 (m, 3H, H-5, H-4 and $\mathrm{H}-1)$, 1.62-1.61 (m, 1H, H-4), 1.50-1.46 (m, 2H, H-5 and H-2), $0.97(\mathrm{t}, \mathrm{J}$ $=7.5 \mathrm{~Hz}, 3 \mathrm{H}, \mathrm{H}-12) .{ }^{13} \mathrm{C}$ NMR: 40.2 (C-1), 53.9 (C-2), 78.7 (C-3), 33.5 (C-4), 30.3 (C-5), 39.8 (C-6), 173.8 (C-7), 29.2 (C-8), 126.9 (C-9), 133.8 (C-10), 20.8 (C-11), 14.4 (C-12); MS: 212[M $\left.{ }^{+}<1 \%\right], 211$ $\left(\mathrm{M}^{+}-1,12 \%\right), 155(11 \%), 142(17 \%), 134(100 \%), 133(25 \%), 119(20 \%), 107(16 \%), 95(12 \%), 79$ $(20 \%)$.

\section{3(R)-Hydroxy-2(R)-(2Z-pentenyl)-cyclopentane-1(R)-acetic acid (2)}

${ }^{1} \mathrm{H}$ NMR: 5.52- $5.37(\mathrm{~m}, 2 \mathrm{H}, \mathrm{H}-10$ and $\mathrm{H}-9), 3.91(\mathrm{dd}, \mathrm{J}=5.2$ and $10.2 \mathrm{~Hz}, 1 \mathrm{H}, \mathrm{H}-3), 2.58(\mathrm{dd}, \mathrm{J}=4.8$ and $15.2 \mathrm{~Hz}, 1 \mathrm{H}, \mathrm{H}-6 \mathrm{a}), 2.34(\mathrm{dd}, \mathrm{J}=8.6$ and $15.5 \mathrm{~Hz}, 1 \mathrm{H}, \mathrm{H}-6 \mathrm{~b}), 2.17-2.12(\mathrm{~m}, 4 \mathrm{H}, \mathrm{H}-11$ and $\mathrm{H}-5)$, 2.09-1.87 (m, 3H, H-8, H-4 and H-1), 1.86-1.52 (m, 1H, H-4), 1.51-1.49 (m, 2H, H-8 and H-2), $0.96(\mathrm{t}, \mathrm{J}$ $=7.4 \mathrm{~Hz}, 3 \mathrm{H}, \mathrm{H}-12) .{ }^{13} \mathrm{C}$ NMR: 39.5 (C-1), 53.6 (C-2), 78.4 (C-3), $33.2(\mathrm{C}-4), 30.0(\mathrm{C}-5), 39.8(\mathrm{C}-6)$, 178.2 (C-7), 29.0 (C-8), 126.5 (C-9), 133.7 (C-10), 20.6 (C-11), 14.2 (C-12). MS: 212 ([M]+ <1\%), 194 (31\%), 165 (20\%), $153(31 \%), 134$ (100\%), $125(41 \%), 91(54 \%), 83(92 \%), 79(88 \%)$. 
${ }^{1} \mathrm{H}$ NMR: $5.33-5.52(\mathrm{~m}, 2 \mathrm{H}, \mathrm{H}-10$ and $\mathrm{H}-9), 4.22$ (ddd, $\mathrm{J}=1.7 ; 4.8$ and $\left.4.8 \mathrm{~Hz}, 1 \mathrm{H}, \mathrm{H}-3\right), 2.55$ (dd, $\mathrm{J}=$ 8.1 and $10.8 \mathrm{~Hz}, 1 \mathrm{H}, \mathrm{H}-6), 2.05-2.22(\mathrm{~m}, 7 \mathrm{H}, \mathrm{H}-8, \mathrm{H}-1, \mathrm{H}-11$ and $\mathrm{H}-5 \alpha), 1.87-1.91(\mathrm{~m}, 1 \mathrm{H}, \mathrm{H}-4), 1.42-$ $1.44(\mathrm{~m}, 1 \mathrm{H}, \mathrm{H}-2), 1.25-1.32(\mathrm{~m}, 1 \mathrm{H}, \mathrm{H}-5 \beta), 0.97(\mathrm{t}, \mathrm{J}=7.6 \mathrm{~Hz}, 3 \mathrm{H}, \mathrm{H}-12) .{ }^{13} \mathrm{C}$ NMR: $38.9(\mathrm{C}-1), 51.2$ (C-2), 74.5 (C-3), 33.4 (C-4), 29.6 (C-5), 39.3 (C-6), 173.8 (C-7), 25.7 (C-8), 127.5 (C-9), 133.1 (C-10), 20.8 (C-11), 14.4 (C-12). MS: 211 ([M]-1 21\%), 155 (48\%), $142(38 \%), 134(100 \%), 119(48 \%), 83$ $(30.5 \%), 79(59 \%)$.

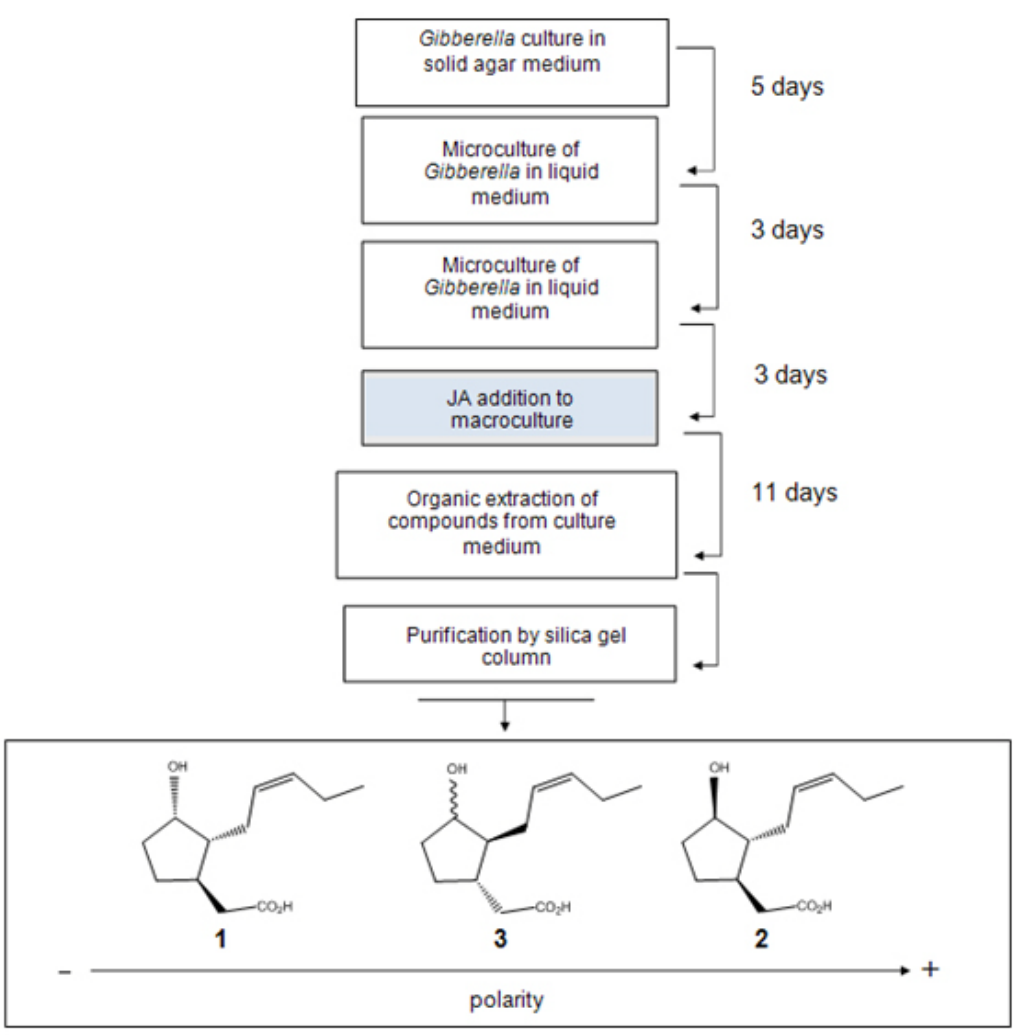

Fig. 2 Culture protocol scheme for biotransformation of JA by using G. fujikuroi fungus. Molecules 1-3 are shown according to the increase of the eluent's polarity (from left to right).

\section{Study on tumor cell lines}

Cell culture and treatments. KB cells (human epidermoid cells) were obtained from American Type Culture Collection (Rockville, MD, USA). Normal human non-immortalized buccal fibroblast cell line was kindly donated by Professor A. Simeone (IIGM, CNR, Naples, Italy).

KB cells (human epidermoid cells) were maintained in RPMI supplemented with $10 \%$ fetal calf serum (FCS), $100 \mathrm{U} / \mathrm{ml}$ penicillin, and $100 \mu \mathrm{g} / \mathrm{ml}$ streptomycin. Normal human non-immortalised buccal fibroblast cells were grown in Dulbecco's modified Eagle's medium (DMEM) supplemented with 10\% fetal calf serum (FCS), $100 \mathrm{U} / \mathrm{ml}$ penicillin, $100 \mu \mathrm{g} / \mathrm{ml}$ streptomycin, and $25 \mu \mathrm{g} / \mathrm{ml}$ fungizone. The cells were plated at a constant density to obtain identical experimental conditions in the different tests, thus to achieve a high accuracy of the measurements. In the MTT assay the cells were plated at $6 \times 10^{3}$ cells per well for human cancer cells, and at $2 \times 10^{4}$ cells per well for normal human non-immortalised buccal fibroblast cells, in a 96-well flat-bottomed $200 \mu \mathrm{l}$ microplate. For other tests, the cancer cells were plated at $8 \times 10^{5}$ cells $(2 \mathrm{ml})$ per $35 \mathrm{~mm}$ culture dish. After $24 \mathrm{hrs}$ incubation at $37^{\circ} \mathrm{C}$ under a humidified $5 \%$ carbon dioxide to allow cell attachment, the cells were treated with different concentrations of JA and its derivatives (1-3), and incubated for 72 hrs under the same conditions. 
Stock solution of the natural products was prepared in DMSO and the final concentration of this solvent was kept constant at $0.25 \%$. Control cultures received DMSO alone.

MTT bioassay. MTT assay was performed as described previously (Russo et al. 2006). Briefly, cells were incubated at $37^{\circ} \mathrm{C}$ in a humidified $5 \% \quad \mathrm{CO}_{2} / 95 \%$ air mixture and treated with different concentrations of JA and its derivatives (1-3) for $72 \mathrm{hrs}$. In some experiments, KB cells were treated by compound $3(25 \mu \mathrm{M})$ with NAC $(500 \mu \mathrm{M})$ for 72 hrs.

Four hours before the end of the treatment time, $20 \mu \mathrm{l}$ of $0.5 \% 3(4,5$-dimethyl-thiazol-2-yl)2,5-diphenyltetrazolium bromide (MTT) in phosphate buffer saline (PBS) were added to each microwell. Cells were washed once before adding MTT. After four hours of incubation at $37^{\circ} \mathrm{C}$, the supernatant was removed and replaced with $100 \mu \mathrm{l}$ of DMSO. The optical density of each well sample was measured with a microplate spectrophotometer reader (Digital and Analog Systems, Rome, Italy) at $550 \mathrm{~nm}$.

Lactate dehydrogenase (LDH) release. Lactate dehydrogenase (LDH) activity was spectrophotometrically measured in the culture medium and in the cellular lysates at $340 \mathrm{~nm}$ by analyzing NADH reduction during the pyruvate-lactate transformation, as previously reported (Russo et al. 2006). Cells were lysed with $50 \mathrm{mM}$ Tris- $\mathrm{HCl}+20 \mathrm{mM}$ EDTA pH $7.4+0.5 \%$ sodium dodecyl sulfate (SDS), further disrupted by sonication and centrifuged at $13,000 \times \mathrm{g}$ for $15 \mathrm{~min}$. The assay mixture (1 $\mathrm{ml}$ final volume) for the enzymatic analysis contained: $33 \mu \mathrm{l}$ of sample (5-10 $\mu \mathrm{g}$ of proteins) in $48 \mathrm{mM}$ PBS pH 7.5 plus $1 \mathrm{mM}$ pyruvate and $0.2 \mathrm{mM} \mathrm{NADH}$. The percentage of LDH released was calculated as percentage of the total amount, considered as the sum of the enzymatic activity present in the cellular lysate and that in the culture medium. A Hitachi U-2000 spectrophotometer (Hitachi, Tokyo, Japan) was used.

DNA analysis by COMET assay. The presence of DNA fragmentation was examined by single cell gel electrophoresis (COMET assay), according to Singh et al. (1991). Briefly, 0.8-1 x $10^{5}$ cells were mixed with $75 \mu \mathrm{l}$ of $0.5 \%$ low melting agarose (LMA) and spotted on slides. The "minigels" were maintained in lysis solution ( $1 \% \mathrm{~N}$-laurosil-sarcosine, $2.5 \mathrm{M} \mathrm{NaCl}, 100 \mathrm{mM} \mathrm{Na} \mathrm{EDDTA}, 1 \%$ Triton X-100, 10\% DMSO, $\mathrm{pH} 10)$ for $1 \mathrm{hr}$ at $4^{\circ} \mathrm{C}$, and then denatured in a high pH buffer $\left(300 \mathrm{mM} \mathrm{NaOH}, 1 \mathrm{mM} \mathrm{Na} \mathrm{EDTA}_{2} \mathrm{pH}\right.$ 13) for $20 \mathrm{~min}$, and finally electrophoresed in the same buffer at $18 \mathrm{~V}$ for $45 \mathrm{~min}$. At the end of the run, the "minigels" were neutralized in $0.4 \mathrm{M}$ Tris- $\mathrm{HCl}, \mathrm{pH} 7.5$, stained with $100 \mu$ l of ethidium bromide $(2$ $\mu \mathrm{g} / \mathrm{ml}$ ) for $10 \mathrm{~min}$ and scored using a fluorescence microscope (Leica, Wetzlar, Germany) interfaced with a computer. Software (Leica-QWIN) allowed to assess the quantitative and qualitative extent of DNA damage by measuring: a) tail length ( $T L)$, intensity $(\mathrm{TI})$ and area (TA); b) head length (HL), intensity ( $\mathrm{HI})$ and area $(\mathrm{HA})$. Finally, the program using these parameters calculates the level of DNA damage as: $i)$ the percentage of the fragmented DNA (TDNA), and ii) tail moment (TMOM). The tail moment is defined as the product of the percentage of DNA in the tail of the comet and TD value,

Table 2. Lactate dehydrogenase (LDH) release in KB cells untreated and treated with jasmonic acid (JA) and compounds 1-3 at different concentrations for $72 \mathrm{hrs}$. Stock solution of compounds was prepared in DMSO and the final concentration of this solvent was kept constant at $0.25 \%$. Control cultures received DMSO alone.

\begin{tabular}{cc}
\hline Treatments & $\begin{array}{c}\text { KB cells } \\
\text { \% LD released }\end{array}$ \\
Control & $4.2 \pm 0.5$ \\
Compound JA & $4.9 \pm 0.3$ \\
$12.5 \mu \mathrm{M}$ & $7.1 \pm 0.7$ \\
$25 \mu \mathrm{M}$ & $6.3 \pm 0.7$ \\
Compound 1 & $6.6 \pm 0.3$ \\
$12.5 \mu \mathrm{M}$ & $6.2 \pm 0.4$ \\
$25 \mu \mathrm{M}$ & $3.9 \pm 0.7$ \\
Compound 2 & \\
$12.5 \mu \mathrm{M}$ & $5.5 \pm 0.6$ \\
$25 \mu \mathrm{M}$ & $4.3 \pm 0.2$ \\
Compound 3 & \\
$12.5 \mu \mathrm{M}$ & \\
$25 \mu \mathrm{M}$ & \\
\hline
\end{tabular}

The results are expressed as percentage of LDH released into the cell medium with respect to total LDH. Each value represents the mean \pm SD of three experiments, performed in quadruplicate. 
which is obtained calculating the distance between the center of mass of the comet head and the center of mass of the tail. The percentage of DNA in the comet tail was calculated as the rate of the fluorescence intensity in the comet tail relative to the total fluorescence; 100 randomly selected cells were analyzed per sample.

Activity of caspase-3. The activity of caspase- 3 was determined by using the Caspase colorimetric assay Kit (SIGMA RBI St. Louis, USA). This assay measures the cleavage of a specific colorimetric caspase substrate, acetyl-Asp-Glu-Val-Asp p-nitroanilide (Ac-DEVD-pNA). pNA (p-nitroaniline) is released from the substrate upon cleavage by caspase. Free pNA produces a yellow colour that is monitored by a Hitachi U-2000 spectrophotometer (Hitachi, Tokyo, Japan) at $\lambda=405 \mathrm{~nm}$. The caspase- 3 activity was measured in cell lysates. The cell pellets were incubated at $4^{\circ} \mathrm{C}$ for 20 min with lysis buffer containing $50 \mathrm{mM}$ HEPES (1-piperazineethane sulfonic acid, 4-(2-hydroxyethyl)monosodium salt), $\mathrm{pH}$ 7.4, $5 \mathrm{mM}$ CHAPS (3[(3-cholamidopropyl)dimethylammonio]-propanesulfonic acid), $5 \mathrm{mM}$ DTT (1,4 dithio-DL-threitol). The lysed cells were centrifuged at 16,000 x g for $15 \mathrm{~min}$ at $4^{\circ} \mathrm{C}$, and the supernatants were analyzed immediately according to the analysis procedure described in the manufacture's protocol.

The total protein content, used to reflect cell number and measured according to Bradford (1976), was evaluated for each sample, and the results are reported as $\mathrm{OD}_{405} \mathrm{~nm} / \mathrm{mg}$ protein and compared to relative control.

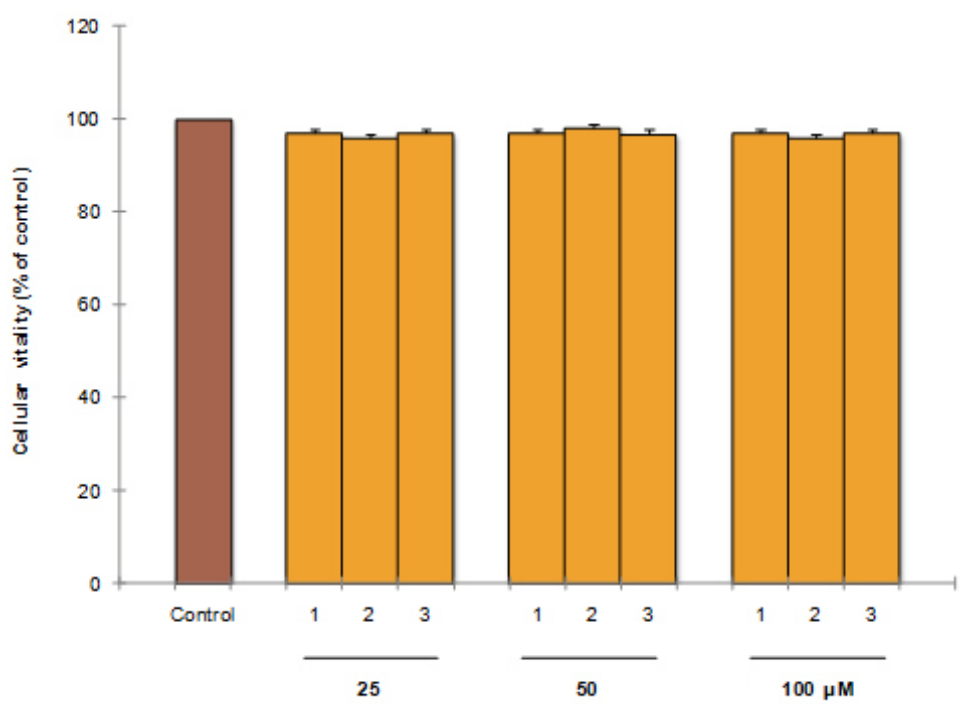

Fig. 3 Cell growth, assayed using MTT test, of normal human buccal fibroblast cells (BFC) untreated and treated with jasmonic acid derivatives 1-3 for $72 \mathrm{hrs}$. Stock solution of the compounds was prepared in DMSO and the final concentration of this solvent was kept constant at $0.25 \%$. Control cultures received DMSO alone. Each value represents the mean \pm SD of three experiments, performed in quadruplicate.

Reactive oxygen species assay. Reactive oxygen species (ROS) determination was performed by using a fluorescent probe 2',7'-dichlorofluorescein diacetate (DCFH-DA), as previously described (Russo et al. 2006). DCFH-DA, diffuses through the cell membrane, and it is enzymatically hydrolysed by intracellular esterases and oxidized to the fluorescent 2',7'-dichlorofluorescein (DCF) in the presence of ROS. The intensity of fluorescence is proportional to the levels of intracellular oxidant species. $100 \mu \mathrm{l}$ of $100 \mu \mathrm{M}$ DCFH-DA, dissolved in $100 \%$ methanol was added to the cellular medium where the acetate group is not hydrolyzed, and the cells were incubated at $37^{\circ} \mathrm{C}$ for $30 \mathrm{~min}$. After incubation, cells were lysated and centrifuged at $10,000 \mathrm{~g}$ for $10 \mathrm{~min}$. The fluorescence (corresponding to the radical species-oxidized 2',7'-dichlorofluorescein, DCF) was monitored spectrofluorometrically using a Hitachi F-2000 spectrofluorimeter (Hitachi, Tokyo, Japan): excitation 488 nm, emission 525 nm. The total protein content, measured according to Bradford (1976) was evaluated for each sample, and the results are reported as fluorescence intensity/mg protein and compared to relative control. 


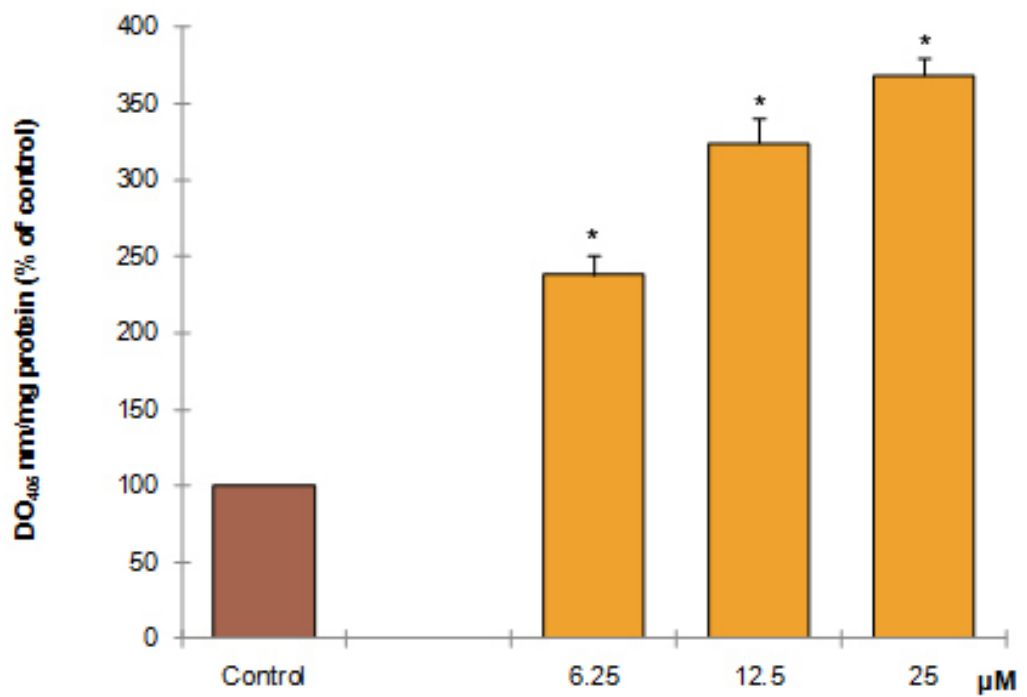

Fig. 4 Effect of the compound 3 in Caspase-3 activity in KB cells. Caspase- 3 activity was determined by using the Caspase colorimetric assay Kit (SIGMA RBI St. Louis, USA), in KB cells untreated and treated with compound 3 at different concentrations for $72 \mathrm{hrs}$. Stock solution of the compound was prepared in DMSO and the final concentration of this solvent was kept constant at $0.25 \%$. Control cultures received DMSO alone. Each value represents the mean \pm SD of three experiments, performed in quadruplicate. *Significant vs. control untreated cells $(p<0.001)$.

\section{Statistical analysis}

Results were analyzed using one-way ANOVA followed by Dunnett's post-hoc test for multiple comparisons with control. All statistical analyses were performed using the statistical software package SYSTAT, version 9 (Systat Inc., Evanston IL, USA).

\section{RESULTS AND DISCUSSION}

\section{Biotransformation experiments and chemical analysis}

The biotransforming capacity of G. fujikuroi mainly on terpene compounds has been well described in the literature (Fraga et al. 2000; Fraga et al. 2003). One the best characterized biotransformation systems using G. fujikuroi is the chemical modification of some precursors of the plant hormone gibberellins (Barrero et al. 2001; Fraga et al. 2004; Fraga et al. 2007). The fungus shows the presence of enzymes involved in the biosynthetic pathway of such type of diterpenoids which might be responsible for the chemical modification of the gibberellin structure (Tudzynski et al. 2003; Malonek et al. 2004; Tudzynski, 2005). Also described has been the ability of this fungus for producing the plant hormone jasmonic acid in small amounts and mainly being detected in the supernatant of the mediaculture (Miersch et al. 1992). This suggests the occurrence of enzymatic activities allowing JA production and a potential machinery able for transforming the chemical structure of this molecule. Indeed, in this work, growth of the fungus G. fujikuroi in a culture media containing JA and analysis of the different extracts by Thin Layer Chromatography (TLC), demonstrated the presence of new bands different to the original JA. Their extraction under neutral conditions ( $\mathrm{pH}$ 6.5-7.0) presented more compounds than any other extracts obtained under basic or acidic conditions. The analysis by TLC showed the presence of new spots with different polarities compared to JA (data not shown). Purification of these spots with increasing gradient solutions of petroleum ether: ethylacetate from 10:3 to $2: 8$ by silica gel columns permitted the separation of three compounds denominated $1,2,3$. The ${ }^{1} \mathrm{H}$ NMR spectra of these fractions demonstrated that all of them displayed a pattern of signals similar to JA. These three compounds $\left(1,2\right.$, and 3 ) also showed ${ }^{1} \mathrm{H}-\mathrm{NMR}$ spectra with similar chemical shifts among them. In addition, all three compounds presented a new signal corresponding, by their chemical displacement, to a hydrogen attached to a carbon (C-3) together with a hydroxyl group. Furthermore, 
the signal of the carbon of the ketone group in the ${ }^{13} \mathrm{C}-\mathrm{NMR}$ spectrum was not observed. The small difference existing in the displacement of this hydrogen $(\mathrm{H}-3)$ between the three derivatives suggested that the carbonyl group was reduced to a hydroxyl group, but with a stereochemistry different to that present in the original JA molecule. In fact, these generated compounds (1, 2 and 3) correspond to the same molecule with different stereochemistry among them.

The hydroxylated molecules generated here (1,2 and 3) by means of the enzymatic action of $G$. fujikuroi correspond to the molecule cucurbic acid (CA) and some of its stereoisomers, a metabolic derivative of JA, whose presence has been detected in both higher plants and fungi in low contents (Dathe et al. 1991; Flescher, 2007). The chemicals synthesis of some isomers of CA has also been reported (Dathe et al. 1991; Miersch et al. 1999a; Seto et al. 1999; Flescher, 2007) and their structurefunction relation in plants has been characterized, suggesting that the essential structural factors of this type of compound pointed to the cis configuration of C-1 and C-2 substituents, the free hydroxyl group at the C-3 position, alkenyl or alkyl group at the C-2 position (Seto et al. 1999). Searching the literature no reports of CA synthesis and stereoisomers of this compound by biotransformation could be found and no reports have been found that account for the antitumor effect of CA and its stereoisomers. Previous reports on JA biotransformation using the fungus Aspergillus niger only mention specific hydroxylations in position C-11 on the jasmonate molecule (Miersch et al. 1999c).

The isomerized product was obtained by biotransformation. The structural determination of 1, 2 and 3was mainly accomplished by ${ }^{1} \mathrm{H},{ }^{13} \mathrm{C}$, DEPT-135, gs-2D (HHCOSY, HSQC and HMBC) NMR techniques and compared with those previously reported (Seto et al. 1999).

In Figure 1 the chemical structures produced by biotransformation of JA with G. fujikuroi are shown. As results of the biotransformations, three hydroxylated compounds of JA were obtained (1, 2 and 3$)$.

The spectra of the derivatives of the JA biotransformation are product of enzymatic activities of this fungus that have not yet been studied nor reported. Relative to the hydroxylated compounds, the existence of reduction reactions of the ketone group in the cyclopentane ring of the original molecule is foreseen due to a possible reductase activity. Important information derived from these derivatives could be drawn, since they are a proof for the existence of stereospecific enzymes not yet informed for G. fujikuroi. Relative to the isomerized derivative corresponding to an isomerization product of the acid hydrogen $(\mathrm{H}-2)$ of $\mathrm{JA}$, it is not known which enzyme could be responsible for generating this modification; autoisomerization is discarded since in the liquid control medium in presence of JA (without fungus) no modification of any type of the compound was observed.

Table 3. Comet assay of genomic DNA in KB cells untreated and treated with compound 3 at different concentrations for $72 \mathrm{hrs}$. Stock solution of compounds was prepared in DMSO and the final concentration of this solvent was kept constant at $0.25 \%$. Control cultures received DMSO alone.

\begin{tabular}{cc}
\hline Treatments & KB cells \\
& TMOM $^{\mathrm{a}}$ \\
Control & $93 \pm 3.4$ \\
Compound 3 & $1096 \pm 18^{*}$ \\
$6.25 \mu \mathrm{M}$ & \\
$12.5 \mu \mathrm{M}$ & $1320 \pm 36^{*}$ \\
$25 \mu \mathrm{M}$ & $2765 \pm 31^{*}$ \\
\hline
\end{tabular}

${ }^{a}$ TMOM= tail moment expressed as the product of TD (distance between head and tail) and TDNA. The values are the mean \pm SD of three experiments performed in quadruplicate. *Significant vs. control untreated cells $(p<0.001)$.

\section{Study on tumor cell lines}

Since antiproliferative screening models in vitro provide important preliminary data to help select compounds with potential antineoplastic properties for future study, JA and its derivatives (1-3) were tested in vitro for their potential human tumour cell growth inhibitory effect on KB cells, using MTT assay, a non-radioactive, fast and economical assay widely used to quantify cell viability and proliferation. MTT is a yellow water-soluble tetrazolium salt. Metabolically active cells are able to convert the dye to water-insoluble dark blue formazan by reductive cleavage of the tetrazolium ring. The results, summarized in Table 1, show that JA and its derivatives (1-3), such as other jasmonate compounds, that are specifically active on several types of cancer cells in different concentration 
ranges (Flescher, 2007), exhibited an inhibitory effect on the human cancer cells examined with different $\mathrm{IC}_{50}$ value. Interestingly, the compound 3 , with the same molecular structure of compounds 1 and 2, but with different stereochemistry, was more active than jasmonic acid against human cancer epithelial cell line, KB cells. These results confirm that the activity of jasmonate compounds is related to their stereochemistry and to substituents in the cyclopentane ring (Miersch et al. 1999b). In addition, the JA derivatives, also at $100 \mu \mathrm{M}$ concentration, revealed no cytotoxic effect against normal human buccal fibroblast cells (BFC) (Figure 3), considered a useful model to evaluate the cytotoxic effects of carcinogens (Galvano et al. 2002) and the tumour-specific cytotoxicity of potential antineoplastic agents (Sekine et al. 2007).

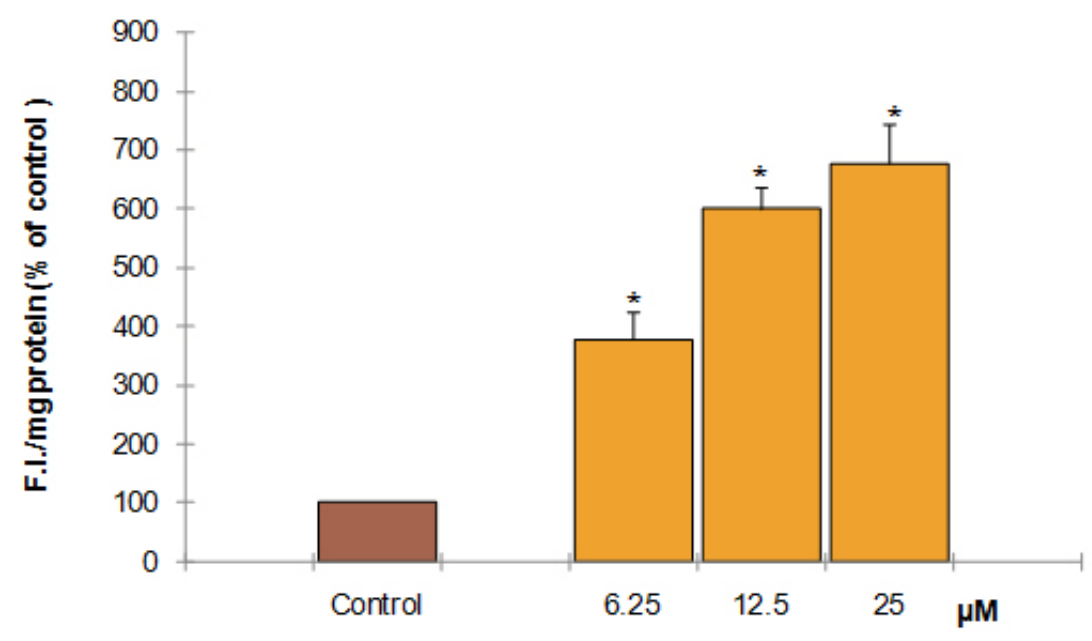

Fig. 5 Reactive oxygen species (ROS) determination in KB cells treated with compound 3. ROS determination was performed by using a fluorescent probe 2',7'-dichlorofluorescein diacetate (DCFH-DA), in KB cells untreated and treated with compound 3 at different concentrations for $72 \mathrm{hrs}$. Stock solution of the compound was prepared in DMSO and the final concentration of this solvent was kept constant at $0.25 \%$. Control cultures received DMSO alone. Each value represents the mean \pm SD of three experiments, performed in quadruplicate. *Significant vs. control untreated cells $(p<0.001)$.

There are many reports that show that members of the plant stress hormones family, and some of their synthetic derivatives, exhibit anti-cancer activity in vitro and in vivo (Fingrut and Flescher, 2002; Flescher, 2007).

Likewise, it is reported the synthesis of numerous and varied series of derivatives of MeJA, predominantly halogenated $(-\mathrm{Cl},-\mathrm{Br},-\mathrm{F})$ structures, which similar to $\mathrm{JA}$ and its derivatives, they exhibit interesting and in some cases potent anti-neoplastic properties (Ishii et al. 2004; Reischer et al. 2007; Park et al. 2010; Zhao et al. 2010), but it is noteworthy that in each of the proposed series does not have reported the production of derivatives with keto group reduced and the potential inhibition of cell growth observed with these series of compounds does not exceed the $\mathrm{IC}_{50}$ obtained with the derivatives reported here.

Qian et al. 2004 reported that synthetic hydroxyl-containing jasmonates may induce different levels of plant defense responses, which are associated with different levels of enhanced metabolic activity for secondary metabolite biosynthesis. This stimulating activity can be explained by the effect of the estereoconfiguration and the optimal lipophilicity and the number of hydroxyl groups. Following the same line of comparison between the effects caused by plant stress hormones and their derivatives in plants under stress and tumour cells would be assumed that the influence on lipophilicity provided by hydroxyl groups present in jasmonates derivatives reported in plants, is also an important factor in the antitumor effect observed in cancer cells; This structural difference could be making the difference in the potential of its activity between jasmonic acid (JA) and its reduced derivative, cucurbic acid (CA).

Cells can die in two different ways: necrosis and apoptosis. Necrosis is caused by outside damage, recognized by destruction of plasma membrane and intracellular organelles and molecules. In 
apoptosis, biochemical and morphological events are usually organized in a cascade of very specific and controlled steps. The beginning of apoptosis is marked by chromatin condensation that occurs in parallel to the shrinking of the cell. Fragmentation of the nucleus, transformation of the cell surface, and complete splitting of the cell contents to apoptotic bodies attached to the membrane, accompany those changes. One of the important features of apoptosis, in most cell lines, is DNA fragmentation, catalyzed by endogenic endonucleases. Final events of apoptosis include activation of specific cytoplasmic proteases named caspases. In mammalian cells, caspases are activated in a cascade, resulting in inappropriate activation or fast damage to structural proteins, as well as to important signaling processes, homeostasis and repair enzymes. Caspase-3 is essential for a number of morphological and biochemical events associated with apoptosis (Shi, 2002). Alterations in apoptotic cell death can lead to a loss of growth control, and thus play a major role in the process of tumorigenesis. Defects of apoptotic pathways influence also drug resistance, and because of these defects chemotherapy often fails (Johnstone et al. 2002). The induction of apoptosis in tumor cells is considered very useful in the management and therapy of cancer (Johnstone et al. 2002). Synthesis or modification of known drugs continues as an important aspect of research. There is a continued need for new templates to be used in the design of potential chemotherapeutic agents. Significantly, natural products are providing such templates. Recent studies on tumor inhibitory compounds of plant origin have yielded an impressive array of novel structures (Ravelo et al. 2004; Cragg and Newman, 2005; Aggarwal and Shishodia, 2006). Despite the structural differences between members of the family of jasmonates and their natural and synthetic derivatives, in general, the mechanism of antitumor action lies in the induction of apoptosis, DNA fragmentation, and increased caspase activity. There are many works that report that cellular stressors induce inhibition of cell proliferation and cell death. Salicylic acid, JA and its methylated derivative (MeJA) are plant stress hormones that activate cellular responses, including cell death, to diverse stress conditions in plants, and also can suppress the proliferation or cause apoptosis in various cancer cells without affecting the normal cells (Flescher, 2007). This data support the potential use of plant stress hormones as selective anti-cancer agents and opens the possibility to use more powerful new derivatives.

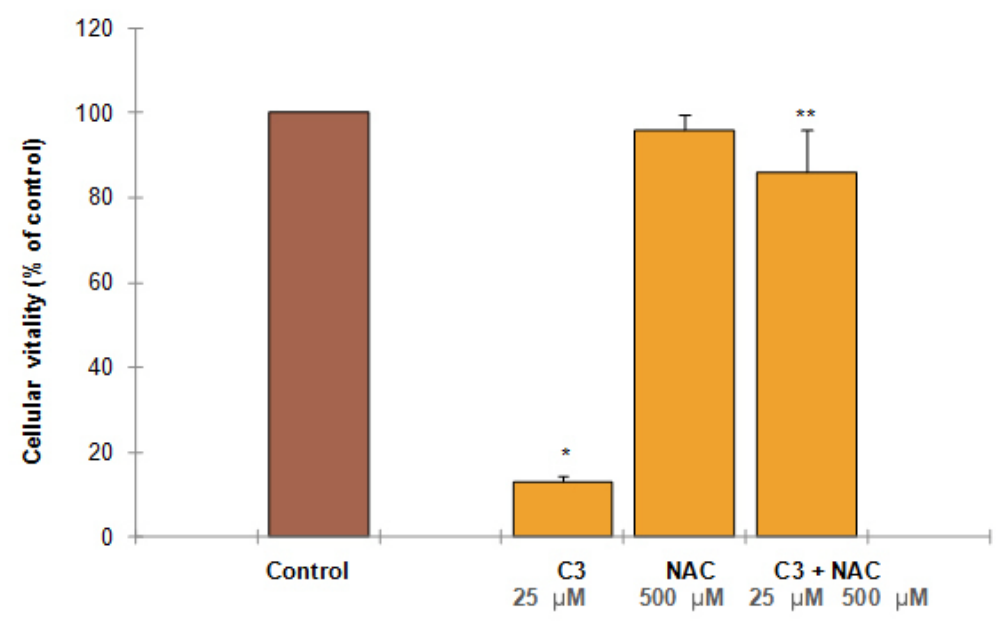

Fig. 6 Cell growth, assayed using MTT test, of KB cells treated and untreated with compound 3 (C3) (25 $\mu M)$ and $\mathrm{N}$-acetylcysteine (NAC) $(500 \mu \mathrm{M})$ for $\mathbf{7 2} \mathrm{hrs}$. Stock solution of the compound 3 was prepared in DMSO and the final concentration of this solvent was kept constant at $0.25 \%$. Control cultures received DMSO alone. Each value represents the mean \pm SD of three experiments, performed in quadruplicate. * Significant vs. control untreated cells $(p<0.001) .{ }^{* *}$ Significant vs. cells treated with compound $3(25 \mu \mathrm{M})(\mathrm{p}<0.001)$.

Consistent with this approach, in this study we tested the potential proapoptotic activity of compound 3, and our data suggest that it, as other jasmonate compounds (Flescher, 2007), is able to trigger apoptotic death in cancer cells. In fact, no statistically significant increase in LDH release (Table 2), a marker of membrane breakdown, correlated to a high DNA fragmentation (Table 3), evidenced by the Comet assay, a versatile tool to distinguish apoptotic from necrotic cells (Russo et al. 2006), was observed in cancer cells treated with this compound at $6.25,12.5$ and $25 \mu \mathrm{M}$ concentrations. The hypothesis of apoptosis induction in our experimental conditions was reinforced by a significant $(p<$ 0.001 ) increase of the caspase-3 enzyme activity (Figure 4). 
ROS have been reported to be involved in cell death induced by a variety of stimuli and different antitumoral agents. Analysis of MJ-induced death in A549 human lung adenocarcinoma cells revealed that MJ-induced apoptosis is correlated to generation of reactive oxygen species (Flescher, 2007). We therefore examined whether cell death induced by compound 3 may be correlated at an elevation of ROS. To assess changes in intracellular ROS levels, we employed an oxidation-sensitive fluorescent probe DCFH-DA. DCFH-DA can be taken up into cells, and then oxidized by ROS to its fluorescent derivative DCF. As supposed, we found that the DCF fluorescence increased in a concentrationdependent manner in the human cancer cells exposed to compound 3 (Figure 5). To confirm the role of ROS in compound 3-induced cell death, KB cells were treated by compound $3(25 \mu \mathrm{M})$ with the antioxidant NAC $(500 \mu \mathrm{M})$ for $72 \mathrm{hrs}$, following which cell viability was determined. NAC control group did not show any significant changes in growth inhibition compared with untreated controls (Figure 6). Treatment with NAC significantly protected cancer cells against the growth inhibitory effect of compound 3 (Figure 6). This suggests that increased ROS generation is essential in compound 3 mediated cell death.

\section{CONCLUDING REMARKS}

Although the compound 3 absolute configuration of carbon five remains to confirm, and of course further studies are needed, taken together, the results shown in this work demonstrated that the production of compounds obtained by the biotransformation of JA with G. fujikuroi may offer a further impulse to the development of the studies towards the optimization of the production in culture media, as well as to be a source for the synthesis of compounds with more potential antitumor activity.

\section{ACKNOWLEDGMENTS}

The authors would like to thank Professor Dr. Robert Verpoorte and Dr. Young Choi for receiving Dr. Marcela Carvajal in their laboratory and their support in nuclear magnetic resonance knowledge, and Professor Peter Fiedler for language and proofreading the manuscript.

Financial support: MC received MECESUP doctoral fellowship (Project-UCV 0206) (PhD program in Biotechnology, Pontificia Universidad Católica de Valparaíso y Universidad Técnica Federico Santa María) and a scholarship rewards SANTANDER UNIVERSIA, Banco Santander Santiago, Chile. Part of this work was funded by Dirección de Investigaciones y Postgrado, Universidad Técnica Federico Santa María.

\section{REFERENCES}

AGGARWAL, B.B. and SHISHODIA, S. (2006). Molecular targets of dietary agents for prevention and therapy of cancer. Biochemical Pharmacology, vol. 71, no. 10, p. 1397-1421. [CrossRef]

ANKLI, A.; HEINRICH, M.; BORK, P.; WOLFRAM, L.; BAUERFEIND, P.; BRUN, R.; SCHMID, C.; WEISS, C.; BRUGGISSER, R.; GERTSCH, J.; WASESCHA, M. and STICHER, O. (2002). Yucatec Mayan medicinal plants: Evaluation based on indigenous uses. Journal of Ethnopharmacology, vol. 79, no. 1, p. 43-52. [CrossRef]

AZERAD, R. (2000). Regio and stereoselective, microbial hydroxylation of terpenoids compounds. In: PATEL, R. ed. Stereoselective Biocatalysis. Marcel Dekker, New York, 2000, p. 153-180.

BARRERO, A.F.; OLTRA, J.E.; CERDÁ-OLMEDO, E.; AVALOS, J. and JUSTICIA, J. (2001). Microbial transformation of ent-kaurenoic acid and its 15-hydroxy derivatives by the SG138 mutant of Gibberella fujikuroi. Journal of Natural Products, vol. 64, no. 2, p. 222-225. [CrossRef]

BOYD, D.R.; SHARMA, N.; LJUBEZ, V.; BYRNE, B.; SHEPHERD, S.; ALLEN, C.; KULAKOV, L.; LARKIN, M. and DALTON, H. (2002). Tandem enzyme-catalysed oxidations of alkyl phenyl sulfides and alkyl benzenes: Enantiocomplementary routes to chiral phenols. Chemical Communications, no. 17, p. 1914-1915. [CrossRef]

BRADFORD, M.M. (1976). A rapid and sensitive method for the quantitation of microgram quantities of protein utilizing the principle of protein-dye binding. Analytical Biochemistry, vol. 72, no. 1-2, p. 248-254. [CrossRef]

BROWSE, J. and HOWE, G.A. (2008). New weapons and a rapid response against insect attack. Plant Physiology, vol. 146 , no. 3, p. 832-838. [CrossRef]

BROWSE, J. (2009). Jasmonate passes muster: A receptor and targets for the defense hormone. Annual Review of Plant Biology, vol. 60, p. 183-205. [CrossRef]

CARDILE, V.; LOMBARDO, L.; SPATAFORA, C. and TRINGALI, C. (2005). Chemo-enzymatic synthesis and cellgrowth inhibition activity of resveratrol analogues. Bioorganic Chemistry, vol. 33, no. 1, p. 22-33. [CrossRef] 
CHANG, F.R.; HSIEH, T.J.; HUANG, T.L.; CHEN, C.Y.; KUO, R.Y.; CHANG, Y.C.; CHIU, H.F. and WU, Y.C. (2002). Cytotoxic constituents of the stem bark of Neolitsea acuminatissima. Journal of Natural Products, vol. 65, no. 3, p. 255-258. [CrossRef]

CREELMAN, R.A. and MULLET, J.E. (1997). Oligosaccharins, brassinolides, and jasmonates: nontraditional regulators of plant growth, development, and gene expression. Plant Cell, vol. 9, no. 7, p. 1211-1223. [CrossRef]

CRAGG, G.M. and NEWMAN, D.J. (2005). Plants as a source of anti-cancer agents. Journal of Ethnopharmacology, vol. 100, no. 1-2, p. 72-79. [CrossRef]

DATHE, W.; SCHINDLER, C.; SCHNEIDER, G.; SCHMIDT, J.; PORZEL, A.; JENSEN, E. and YAMAGUCHI, I. (1991). Cucurbic acid and its 6,7-stereoisomers. Phytochemistry, vol. 30, no. 6, p. 1909-1914. [CrossRef]

DOMBROWSKI, J. (2003). Salt stress activation of wound-related genes in tomato plants. Plant Physiology, vol. 132, no. 4, p. 2098-2107. [CrossRef]

FINGRUT, O. and FLESCHER, E. (2002). Plant stress hormones suppress the proliferation and induce apoptosis in human cancer cells. Leukemia, vol. 16, no. 4, p. 608-616. [CrossRef]

FLESCHER, E. (2007). Jasmonates in cancer therapy. Cancer Letters, vol. 245, no. 1-2, p. 1-10. [CrossRef]

FRAGA, B.M.; HERNÁNDEZ, M.; GONZÁLEZ, P.; CHAMY, M.C. and GARBARINO, J. (2000). The biotransformation of 18-hidroxy-9-epi-ent-pimara-7,15-diene by Gibberella fujikuroi. Phytochemistry, vol. 53, no. 3, p. 395-399. [CrossRef]

FRAGA, B.M.; GONZÁLEZ, P.; HENÁNDEZ, M.; CHAMY, M.C. and GARBARINO, J. (2003). Microbial transformation of 18-hydroxy-9,13-epi-ent-pimara-7,15-diene by Gibberella fujikuroi. Journal of Natural Products, vol. 66, no. 3, p. 392-397. [CrossRef]

FRAGA, B.M.; GUILLERMO, R. and HERNÁNDEZ, M.G. (2004). The microbiological transformation of two $15 \beta-$ hydroxy-ent-kaurene diterpenes by Gibberella fujikuroi. Journal of Natural Products, vol. 67, no. 1, p. 64-69. [CrossRef]

FRAGA, B.M.; BRESSA, C.; GONZÁLEZ, P.; GUILLERMO, R.; HERNÁNDEZ, M.G. and SUÁREZ, S. (2007). The microbiological transformation of 7-a-hydroxy-ent-kaur-16-ene derivatives by Gibberella fujikuroi. Phytochemistry, vol. 68, no. 11, p. 1557-1563. [CrossRef]

GALVANO, F.; RUSSO, A.; CARDILE, V.; GALVANO, G.; VANELLA, A. and RENIS, M. (2002). DNA damage in human fibroblasts exposed to Fumonisin $B_{1}$. Food and Chemical Toxicology, vol. 40, no. 1, p. $25-31$. [CrossRef]

HEINRICH, M. and GIBBONS, S. (2001). Ethnopharmacology in drug discovery: An analysis of its role and potential contribution. Journal of Pharmacy and Pharmacology, vol. 53, no. 4, p. 425-432. [CrossRef]

HERMAN, M.A.B.; DAVIDSON, J.K. and SMART, C.D. (2008). Induction of plant defense gene expression by plant activators and Pseudomonas syringae pv. tomato in greenhouse-grown tomatoes. Phytopathology, vol. 98, no. 11, p. 1226-1232. [CrossRef]

ISHII, Y.; KIYOTA, H.; SAKAI, S. and HONMA, Y. (2004). Induction of differentiation of human myeloid leukemia cells by jasmonates, plant hormones. Leukemia, vol. 18, no. 8, p. 1413-1419. [CrossRef]

JOHNSTONE, R.W.; RUEFLI, A.A. and LOWE, S.W. (2002). Apoptosis: A link between cancer genetics and chemotherapy. Cell, vol. 108, no. 2, p. 153-164. [CrossRef]

JULSING, M.; KOULMAN, A.; WOERDENBAG, H.; QUAX, W. and KAYSER, O. (2006). Combinatorial biosynthesis of medicinal plant secondary metabolites. Biomolecular Engineering, vol. 23, no. 6, p. 265-279. [CrossRef]

KESSLER, A. and BALDWIN, I. (2002). Plant responses to insect herbivory: The emerging molecular analysis. Annual Review of Plant Biology, vol. 53, p. 299-328. [CrossRef]

KNIAZHANSKI, T.; JACKMAN, A.; HEYFETS, A.; GONEN, P.; FLESCHER, E. and SHERMAN, L. (2008). Methyl jasmonate induces cell death with mixed characteristics of apoptosis and necrosis in cervical cancer cells. Cancer Letters, vol. 271, no. 1, p. 34-46. [CrossRef]

LEHMAN, L. and STEWART, J. (2001). Filamentous fungi potentially useful catalysts for the biohydroxylations of non-activated carbon centers. Current Organic Chemistry, vol. 5, no. 4, p. 439-470. [CrossRef]

LERESCHE, J.E. and MEYER, H.P. (2006). Chemocatalysis and biocatalysis (biotransformation): Some thoughts of a chemist and of a biotechnologist. Organic Process Research and Development, vol.10, no. 3, p. 572-580. [CrossRef]

LI, X.; SCHULER, M. and BERENBAUM, M. (2002). Jasmonate and salicylate induce expression of herbivore cytochrome $\mathrm{P}_{450}$ genes. Nature, vol. 419, no. 6908, p. 712-715. [CrossRef]

MALONEK, S.; ROJAS, M.C.; HEDDEN, P.; GASKIN, P. HOPKINS, P. and TUDZYNSKI, B. (2004). The NADPHcytochrome P450 reductase gene from Gibberella fujikuroi is essential for gibberellin biosynthesis. The Journal of Biological Chemistry, vol. 279, no. 24, p. 25075-25084. [CrossRef]

MIERSCH, O.; BRÜCKNER, B.; SCHMIDT, J. and SEMBDNER, G. (1992). Cyclopentane fatty acids from Gibberella fujikuroi. Phytochemistry, vol. 31, no. 11, p. 3835-3837. [CrossRef]

MIERSCH, O.; BOHLMANN, H. and WASTERNACK, C. (1999a). Jasmonates and related compounds from Fusarium oxysporum. Phytochemistry, vol. 50, no. 4, p. 517-523. [CrossRef]

MIERSCH, O.; KRAMELL, R.; PARTHIER, B. and WASTERNACK, C. (1999b). Structure-activity relations of substituted, deleted or stereospecifically altered jasmonic acid in gene expression of barley leaves. Phytochemistry, vol. 50, no. 3, p. 353-361. [CrossRef]

MIERSCH, O.; PORZEL, A. and WASTERNACK, C. (1999c). Microbial conversion of jasmonates-hydroxylations by Aspergillus niger. Phytochemistry, vol. 50, no. 7, p. 1147-1152. [CrossRef]

MIERSCH, O.; NEUMERKEL, J.; DIPPE, M.; STENZEL, I. and WASTERNACK, C. (2008). Hydroxylated jasmonates are commonly occurring metabolites of jasmonic acid and contribute to a partial switch-off in jasmonate signaling. New Phytologist, vol. 177, no. 1, p. 114-127. [CrossRef] 
PARK, C.; JIN, C.Y.; KIM, G.Y.; CHEONG, J.; JUNG, J.H.; YOO, Y.H. and CHOI, Y.H. (2010). A methyl jasmonate derivative, J-7, induces apoptosis in human hepatocarcinoma Hep3B cells in vitro. Toxicology in vitro, vol. 24, no. 7, p. 1920-1926. [CrossRef]

QIAN, Z.-G.; ZHAO, Z.-J.; XU, Y.; QIAN, X. and ZHONG, J.-J. (2004). Novel chemically synthesized hydroxylcontaining jasmonates as powerful inducing signals for plant secondary metabolism. Biotechnology and Bioengineering, vol. 86, no. 7, p. 809-816. [CrossRef]

RAO, M.; LEE, H.; CREELMAN, R.; MULLET, J. and DAVIS, K. (2000). Jasmonic acid signaling modulates ozoneinduced hypersensitive cell death. The Plant Cell, vol. 12, no. 9, p. 1633-1646. [CrossRef]

RAO, M.; VENKATESHAM, U.; SRIDEVI, K.; JAMIL, K. and VENKATESWARLU, Y. (2002). Biotransformations, antibacterial evaluations of the sesquiterpenoids and diterpenoids. Indian Journal of Chemistry, vol. 41, no. 7 , p. $1472-1476$

RAVELO, A.G.; ESTEVEZ-BRAUN, A.; CHAVEZ-ORELLANA, H.; PEREZ-SACAU, E. and MESA-SIVERIO, D. (2004). Recent studies on natural products as anticancer agents. Current Topics in Medicinal Chemistry, vol. 4, no. 2, p. 241-265.

REISCHER, D.; HEYFETS, A.; SHIMONY, S.; NORDENBERG, J.; KASHMAN, Y. and FLESCHER, E. (2007). Effects of natural and novel synthetic jasmonates in experimental metastatic melanoma. British Journal of Pharmacology, vol. 150, no. 6, p. 738-749. [CrossRef]

RICHARDSON, M.A. (2001). Biopharmacologic and herbal therapies for cancer: Research update from NCCAM. The Journal of Nutrition, vol. 131, no. 11, p. 3037-3040.

ROBERTS, S.M. (2000). Using microorganisms in synthetic organic chemistry. Journal of Chemical Education, vol. 77, no. 3, p. 344-348. [CrossRef]

ROTEM, R.; FINGRUT, O.; MOSKOVITZ, J. and FLESCHER, E. (2003). The anticancer plant stress-protein methyl jasmonate induces activation of stress-regulated c-Jun N-terminal kinase and p38 protein kinase in human lymphoid cells. Leukemia, vol. 17, no. 11, p. 2230-2234. [CrossRef]

RUSSO, A.; PIOVANO, M.; LOMBARDO, L.; VANELLA, L.; CARDILE, V. and GARBARINO, J. (2006). Pannarin inhibits cell growth and induces cell death in human prostate carcinoma DU-145 cells. Anti-Cancer Drugs, vol. 17, no. 10, p. 1163-1169. [CrossRef]

SEKINE, T.; TAKAHASHI, J.; NISHISHIRO, M.; ARAI, A.; WAKABAYASHI, H.; KURIHARA, T.; KOBAYASHI, M.; HASHIMOTO, K.; KIKUCHI, H.; KATAYAMA, T.; KANDA, Y.; KUNII, S.; MOTOHASHI, N. and SAKAGAMI, $\mathrm{H}$. (2007). Tumor-specific and type of cell death induced by trihaloacetylazulenes in human tumor cell lines. Anticancer Research, vol. 27, no. 1A, p. 133-143.

SETO, H.; NOMURA, E.; FUJIOKA, S.; KOSHINO, H.; SUENEGA, T. and YOSHIDA, S. (1999). Easy preparation of methyl 7-epi-jasmonate and four stereoisomers of methyl cucurbate, and assessment of the stereogenic effect of jasmonate on phytohormonal activities. Bioscience, Biotechnology and Biochemistry, vol. 63, no. 2, p. 361-367. [CrossRef]

SHAN, X-Y.; WANG, Z-L. and XIE, D. (2007). Jasmonate signal pathway in Arabidopsis. Journal of Integrative Plant Biology, vol. 49, no. 1, p. 81-86. [CrossRef]

SHI, Y. (2002). Mechanisms of caspase activation and inhibition during apoptosis. Molecular Cell, vol. 9, no. 3, p. 459-470. [CrossRef]

SINGH, N.P.; TICE, R.R.; STEPHENS, R.E. and SCHNEIDER, E.L. (1991). A microgel electrophoresis technique for the direct quantitation of DNA damage and repair in individual fibroblasts cultured on microscope slides. Mutation Research/Environmental Mutagenesis and Related Subjects, vol. 252, no. 3, p. 289-296. [CrossRef]

STASWICK, P. (2009). The tryptophan conjugates of jasmonic and indole-3-acetic acids are endogenous auxin inhibitors. Plant Physiology, vol. 150, no. 3, p. 1310-1321. [CrossRef]

STRATMANN, J. (2003). Ultraviolet-B radiation co-opts defense signaling pathways. Trends in Plant Science, vol. 8, no. 11, p. 526-533. [CrossRef]

TATMAN, D. and MO, H. (2002). Volatile isoprenoid constituents of fruits, vegetables and herbs cumulatively suppress the proliferation of murine B16 melanoma and human HL-60 leukemia cells. Cancer Letters, vol. 175, no. 2, p. 129-139. [CrossRef]

TUDZYNSKI, B.; MIHLAN, M.; ROJAS, M.C.; LINNEMANNSTÖNS, P.; GASKIN, P. and HEDDEN, P. (2003). Characterization of the final two genes of the gibberellin biosynthesis gene cluster of Gibberella fujikuroi des and P450-3 encode $\mathrm{GA}_{4}$ desaturase and the 13-hydroxylase, respectively. The Journal of Biological Chemistry, vol. 278, no. 31, p. 28635-28643. [CrossRef]

TUDZYNSKI, B. (2005). Gibberellin biosynthesis in fungi: Genes, enzymes, evolution, and impact on biotechnology. Applied Microbiology and Biotechnology, vol. 66, no. 6, p. 597-611. [CrossRef]

TURNER, J.; ELLIS, C. and DEVOTO, A. (2004). The jasmonate signal pathway. Plant Cell, vol. 14, p. S153-S164.

WARGOVICH, M.J.; WOODS, C.; HOLLIS, D.M. and ZANDER, M.E. (2001). Herbals, cancer prevention and health. The Journal of Nutrition, vol. 131, no. 11, p. 3034S-3036S.

WASTERNACK, C. and HAUSE, B. (2002). Jasmonates and octadecanoids: Signals in plant stress responses and development. Progress in Nucleic Acid Research and Molecular Biology, vol. 72, p. 165-221. [CrossRef]

WASTERNACK, C. (2007). Jasmonates: An update on biosynthesis, signal transduction and action in plant stress response, growth and development. Annals of Botany, vol. 100, no. 4, p. 681-697. [CrossRef]

ZHAO, J.; KANG, S.; ZHANG, X.; YOU, S.; PARK, J.S.; JUNG, J.H. and KIM, D.K. (2010). Apoptotic activity of a new jasmonate analogue is associated with its induction of DNA damage. Oncology Reports, vol. 24, no. 3, p. 771-777. [CrossRef] 


\section{How to cite this article:}

CARVAJAL, M.; ESPINOZA, L.; CAGGIA, S.; CARDILE, V.; GARBARINO, J.A.; PEÑA-CORTÉS, $\mathrm{H}$. and RUSSO, A. (2011). New stereoisomeric derivatives of jasmonic acid generated by biotransformation with the fungus Gibberella fujikuroi affect the viability of human cancer cells. Electronic Journal of Biotechnology, vol. 14, no. 2 http://dx.doi.org/10.2225/vol14-issue2-fulltext-11 